\title{
Immature embryo: A useful tool for oil palm (Elaeis guineensis Jacq.) genetic transformation studies
}

\author{
Ruslan Abdullah* \\ School of Bioscience and Biotechnology \\ Faculty of Science and Technology \\ Universiti Kebangsaan Malaysia \\ 43600 UKM-Bangi, Selangor, Malaysia \\ Tel/Fax: 60389215698 \\ E-mail: russzn@ukm.my
}

\author{
Alizah Zainal \\ School of Bioscience and Biotechnology \\ Faculty of Science and Technology \\ Universiti Kebangsaan Malaysia \\ 43600 UKM-Bangi, Selangor, Malaysia \\ Tel: 60389213386 \\ Fax: 603-89212698 \\ Wee Yew Heng \\ School of Bioscience and Biotechnology \\ Faculty of Science and Technology \\ Universiti Kebangsaan Malaysia \\ 43600 UKM-Bangi, Selangor, Malaysia \\ Tel/Fax: 60389215698

\section{Leaw Chui Li} \\ School of Bioscience and Biotechnology \\ Faculty of Science and Technology \\ Universiti Kebangsaan Malaysia \\ 43600 UKM-Bangi, Selangor, Malaysia \\ Tel/Fax: 60389215698

\section{Yeap Chee Beng} \\ School of Bioscience and Biotechnology \\ Faculty of Science and Technology \\ Universiti Kebangsaan Malaysia \\ 43600 UKM-Bangi, Selangor, Malaysia \\ Tel/Fax: 60389215698

\section{Lee Mei Phing} \\ School of Bioscience and Biotechnology \\ Faculty of Science and Technology \\ Universiti Kebangsaan Malaysia \\ 43600 UKM-Bangi, Selangor, Malaysia \\ Tel/Fax: 60389215698 \\ E-mail:phing_san@yahoo.com
}

\section{Salwa Abdullah Sirajuddin}

School of Bioscience and Biotechnology Faculty of Science and Technology Universiti Kebangsaan Malaysia 43600 UKM-Bangi, Selangor, Malaysia

Tel/Fax: 60389215698

E-mail: adeq_fawaz@lycos.com

Winnie Yap Soo Ping

Malaysia Multimedia University Jalan Ayer Keroh Lama, 75450 Bukit Beruang Melaka, Malaysia

E-mail: spyap@mmu.edu.my

\section{Juanita Lourdes Joseph}

TropBio Research Sdn Bhd 

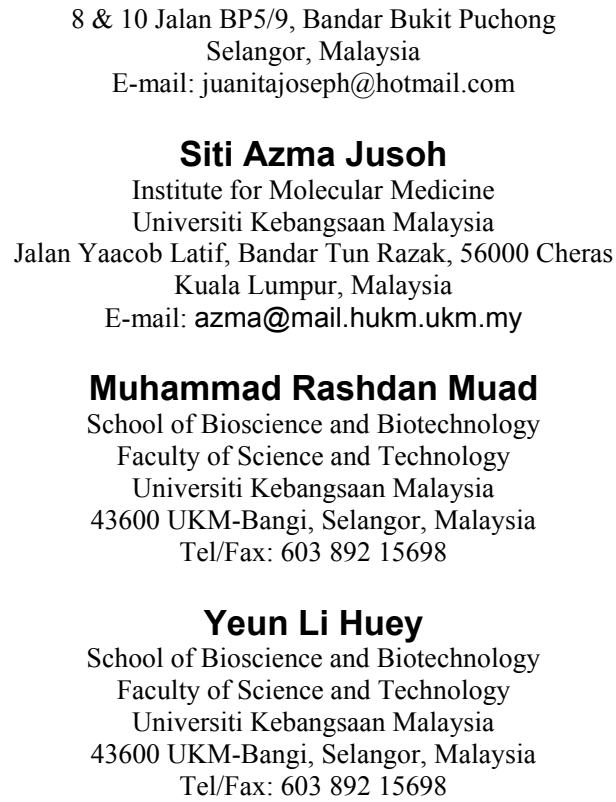

Financial support: Ministry of Science Technology and the Innovations, Malaysia.

Keywords: genetic transformation studies, immature embryos, in vitro culture, oil palm, plant regeneration.

Oil palm (Elaeis guineensis Jacq.) is the highest yielding oil-bearing crop. However, being a perennial crop, genetic improvement of oil palm is extremely slow. Indeed, compared to other annual oil crops such as soybean and rapeseed, genetic manipulations remained less important. Therefore, to remain competitive, oil palm growers and breeders need new and novel approaches. In this report, the potential of immature embryos (IE) as a useful tool for oil palm genetic transformation studies was evaluated. It was evident that IEs were amenable to both direct and Agrobacterium-mediated gene transfer. Due to the abundant supply of IE, optimization of biolistic and Agrobacterium-mediated gene transfer into IEs were easily carried out. Transient transformation frequencies were comparable to other plant systems reported, with as high as $97.4 \%$ recorded for biolistic and $64.4 \%$ for Agrobacterium-mediated gene transfer. Like most moncots, oil palm tissues were less sensitive to kanamycin, geneticin and chloramphenicol. Instead, both hygromycin and phosphinotrycin were toxic 20 mg/l, making both suitable candidates for selecting putative transformants. IEs were also more responsive to in vitro manipulations as compared to other explants such as leaf and root tissues. Rapid in vitro response to callusing and embryogenesis or rapid and highly efficient direct germination resulted in a shorter culture period. This would minimize the production of abnormal abnormal clonal palms, which has been associated to chromosomal aberration due to prolonged time in culture. In addition, IEs also allows rapid and direct introduction of elite genes into breeding programs and in biclonal seed production.

Oil palm (Elaeis guineensis Jacq.) is a perennial monocot with a long generation period of about 20 years. Thus, oil palm breeding is a very slow process. Innovative methods are needed to enhance the incorporation of new genetic resources into oil palm. Initially, tissue culture techniques were used to propagate elite oil palm clones (Jones, 1974). Unfortunately, some early clonal palms produced through tissue culture were abnormal (Corley et al. 1986). However, oil palm tissue culture techniques have undergone continuous improvement on over a period of more than 20 years. This resulted in the production of clonal palms with minimal abnormality (Jones, 1995; Rival et al. 1998). In addition, early results from several field trials on clonal palms have shown encouraging yield improvement (Corley et al. 1993). Therefore, clonal palms are expected to eventually replace seed-derived planting materials on a commercial scale.

Complete plants have been successfully regenerated from various explants of oil palm. They include mature and immature embryos, apical meristems, embryogenic cell suspension cultures, friable embryogenic tissues and callus derived from seedlings, roots, inflorescences and young

*Corresponding author 
Table 1. Media composition for oil palm tissue culture and genetic transformation studies.

\begin{tabular}{|c|c|c|c|c|}
\hline Media Code & $\mathrm{N}_{6} \mathrm{O}$ & $\mathrm{N}_{6} 2.5$ & $\mathrm{~N}_{6} \mathrm{FET}$ & R68 \\
\hline Basic Media & $\mathrm{N}_{6}{ }^{\mathrm{a}}$ & $\mathrm{N}_{6}{ }^{\mathrm{a}}$ & $\mathrm{N}_{6}{ }^{a}$ & $\mathrm{~B}_{5}^{\mathrm{b}}$ \\
\hline \multicolumn{5}{|c|}{ Macronutrients (mg/l) } \\
\hline $\mathrm{CaCl}_{2} 2 \mathrm{H}_{2} \mathrm{O}$ & 166 & 166 & 166 & - \\
\hline $\mathrm{CaCl}$ & - & - & - & 113.24 \\
\hline $\mathrm{KH}_{2} \mathrm{PO}_{4}$ & 400 & 400 & 400 & - \\
\hline $\mathrm{NaH}_{2} \mathrm{PO}_{4}$ & - & - & - & 130.5 \\
\hline $\mathrm{MgSO}_{4} 7 \mathrm{H}_{2} \mathrm{O}$ & 185 & 185 & 185 & - \\
\hline $\mathrm{MgSO}_{4}$ & - & - & - & 112.09 \\
\hline KNO3 & 2830 & 2830 & 2830 & 2500 \\
\hline$\left(\mathrm{NH}_{4}\right)_{2} \mathrm{SO}_{4}$ & 463 & 463 & 463 & 134 \\
\hline \multicolumn{5}{|c|}{ Micronutrients (mg/l) } \\
\hline $\mathrm{KI}$ & 0.8 & 0.8 & 0.8 & 0.75 \\
\hline $\mathrm{H}_{3} \mathrm{BO}_{3}$ & 1.6 & 1.6 & 1.6 & 3 \\
\hline $\mathrm{MnSO}_{4} 4 \mathrm{H}_{2} \mathrm{O}$ & 4.4 & 4.4 & 4.4 & 10 \\
\hline $\mathrm{ZnSO}_{4} 7 \mathrm{H}_{2} \mathrm{O}$ & 1.5 & 1.5 & 1.5 & 2 \\
\hline $\mathrm{CoCl}_{2} 6 \mathrm{H}_{2} \mathrm{O}$ & - & - & - & 0.025 \\
\hline $\mathrm{CuSO}_{4} 5 \mathrm{H}_{2} \mathrm{O}$ & - & - & - & 0.025 \\
\hline $\mathrm{Na}_{2} \mathrm{MoO}_{4} 2 \mathrm{H}_{2} \mathrm{O}$ & - & - & - & 0.25 \\
\hline $\mathrm{FeSO}_{4} 7 \mathrm{H}_{2} \mathrm{O}$ & 27.85 & 27.85 & 27.85 & 27.85 \\
\hline $\mathrm{Na}_{2}$ EDTA & 37.25 & 37.25 & 37.25 & 37.25 \\
\hline \multicolumn{5}{|c|}{ Vitamins and sugars (mg/l) } \\
\hline Myo-inositol & 100 & 100 & 110 & 100 \\
\hline Nicotinic acid & 0.5 & 0.5 & 500 & 1 \\
\hline Pyridoxine- $\mathrm{HCl}$ & 0.5 & 0.5 & - & 1 \\
\hline Thiamine- $\mathrm{HCl}$ & 1.0 & 1.0 & - & 10 \\
\hline Ascorbic acid & - & - & 250 & - \\
\hline Sucrose & 30000 & 30000 & 30000 & 30000 \\
\hline Kao's vitamins ${ }^{c}$ & - & - & $1 X$ & - \\
\hline Y3 vitamins ${ }^{\mathrm{d}}$ & - & - & $1 \mathrm{X}$ & - \\
\hline \multicolumn{5}{|c|}{ Amino acids, hormones and antibiotics (mg/l) } \\
\hline $2,4-\mathrm{D}$ & - & 2.5 & 110 & 0.1 \\
\hline Cysteine & - & - & 500 & - \\
\hline \multicolumn{5}{|c|}{ Others (mg/l) } \\
\hline Gelrite & 2200 & 2200 & 2200 & 2200 \\
\hline PVP-40 & - & - & 5000 & - \\
\hline Activated Charcoal & - & - & 3000 & 3000 \\
\hline $\mathrm{pH}$ & 5.8 & 5.8 & 5.8 & 5.8 \\
\hline
\end{tabular}

a. Chu et al. 1975;

b. Gamborg et al. 1976 ;

c. Kao's vitamins: $100 \mathrm{mg} / \mathrm{l}$ myo-inositol, $1 \mathrm{mg} / \mathrm{l}$ nicotinic acid, $1 \mathrm{mg} / \mathrm{l}$ pyridoxine $\mathrm{HCl}, 1 \mathrm{mg} / \mathrm{l}$ Thiamine $\mathrm{HCl}, 1 \mathrm{mg} / \mathrm{l}$ D-calcium panthothenate, $0.4 \mathrm{mg} / \mathrm{l}$ folic acid, $0.02 \mathrm{mg} / \mathrm{l}$ p-aminobenzoic acid, $0.01 \mathrm{mg} / \mathrm{l}$ biotin, $1 \mathrm{mg} / \mathrm{l}$ choline chloride, $0.2 \mathrm{mg} / \mathrm{l}$ riboflavin, 2 $\mathrm{mg} / \mathrm{l}$ ascorbic acid, $0.01 \mathrm{mg} / \mathrm{l}$ vitamin A, $0.01 \mathrm{mg} / \mathrm{l}$ vitamin D3 and $0.02 \mathrm{mg} / \mathrm{l}$ vitamin B12;

d. Y3 vitamins: $100 \mathrm{mg} / \mathrm{L}$-glutamine, $120 \mathrm{mg} / \mathrm{L}$ L-arginine, $88 \mathrm{mg} / \mathrm{L}$-asparagine, $100 \mathrm{mg} / \mathrm{l}$ myo-inositol, $1 \mathrm{mg} / \mathrm{l}$ nicotinic acid, 1 $\mathrm{mg} / \mathrm{l}$ pyridoxine $\mathrm{HCl}, 1 \mathrm{mg} / \mathrm{l}$ Thiamine $\mathrm{HCl}$; 
Table 2. Transient expression of GUS activity in immature embryos and plants derived from bombarded immature embryos.

(a). Influence of macrocarrier gap on transient transformation frequency on bombarded immature embryos. Data collated from 9 replicates made of 50-70 embryos per bombardment for each macrocarrier gap evaluated. Transient transformation frequency was scored based on immature embryos showing gus expression 3 days after bombardment.

\begin{tabular}{|c|c|c|c|}
\hline $\begin{array}{c}\text { Macrocarrier gap } \\
(\mathbf{m m})\end{array}$ & \% transient transformation & $\mathbf{K m}^{\mathbf{r}}$ plants & \% $\mathbf{K m}^{\mathrm{r}}$ plants with gus activity \\
\hline 6 & $56.43 \pm 30.67$ & $20.78 \pm 17.89$ & $4.03 \pm 3.82$ \\
\hline 11 & $67.55 \pm 17.84$ & $32.89 \pm 13.90$ & $44.92 \pm 29.69$ \\
\hline 16 & $65.51 \pm 15.63$ & $51.67 \pm 31.87$ & $22.79 \pm 13.47$ \\
\hline
\end{tabular}

(b). Influence of helium pressure on transient transformation frequency on bombarded immature embryos. Data collated from 9 replicates made of 50-70 embryos per bombardment for each helium pressure evaluated. Transient transformation frequency was scored based on immature embryos showing gus expression 3 days after bombardment.

\begin{tabular}{|c|c|c|c|}
\hline Helium pressure (psi) & \% transient transformation & $\mathbf{K m}^{\text {r }}$ plants & \% Km plants with gus activity \\
\hline 900 & $67.36 \pm 17.41$ & $44.89 \pm 25.38$ & $31.31 \pm 22.42$ \\
\hline 1100 & $59.32 \pm 24.28$ & $16.83 \pm 13.76$ & $14.66 \pm 30.90$ \\
\hline 1300 & $59.32 \pm 27.80$ & $31.67 \pm 23.04$ & $23.09 \pm 27.58$ \\
\hline
\end{tabular}

(c). Influence of embryo size on transient transformation frequency on bombarded immature embryos. Data collated from 9 replicates made of 50-70 embryos per bombardment for each embryo size evaluated. Transient transformation frequency was scored based on immature embryos showing gus expression 3 days after bombardment.

\begin{tabular}{|c|c|c|c|}
\hline Embryo size $(\mathbf{m m})$ & \% transient transformation & $\mathbf{K m}^{\mathrm{r}}$ plants & \% Km plants with gus activity \\
\hline$<3$ & $68.98 \pm 26.61$ & $22.33 \pm 15.80$ & $14.70 \pm 18.27$ \\
\hline $3-6$ & $49.67 \pm 26.57$ & $22.50 \pm 14.43$ & $39.96 \pm 38.96$ \\
\hline$>6$ & $67.67 \pm 10.13$ & $43.11 \pm 26.71$ & $20.96 \pm 19.15$ \\
\hline
\end{tabular}

leaves (Texeira et al. 1993; Texeira et al. 1994). The frequencies for complete plant regeneration from some explants are still inefficient (Rival et al. 1999). Nevertheless, it has become almost routine in many laboratories. As in the case for most monocots, the introduction of foreign genes into oil palm has been limited due to the lack of an efficient, reliable and rapid regeneration system (Ayres and Park, 1994). But the ability to regenerate complete plants from all the above explants has made oil palm amenable to genetic manipulation for the incorporation of foreign gene(s) (Murphy, 1999). Not all explants, however, are suitable for genetic manipulation studies.

Following recent advances in genetic transformation studies, it is possible to transfer any foreign genes into any targeted plant genome. Oil palm is no exception. One routine technique is by using Agrobacterium spp. (Gelvin, 2003). Unfortunately, until recently, the hosts for Agrobacterium have been limited to dicots and a few monocots. To date, there has been no report on the susceptibility of oil palm tissues to Agrobacterium infection. Alternatively, DNA could be delivered directly 


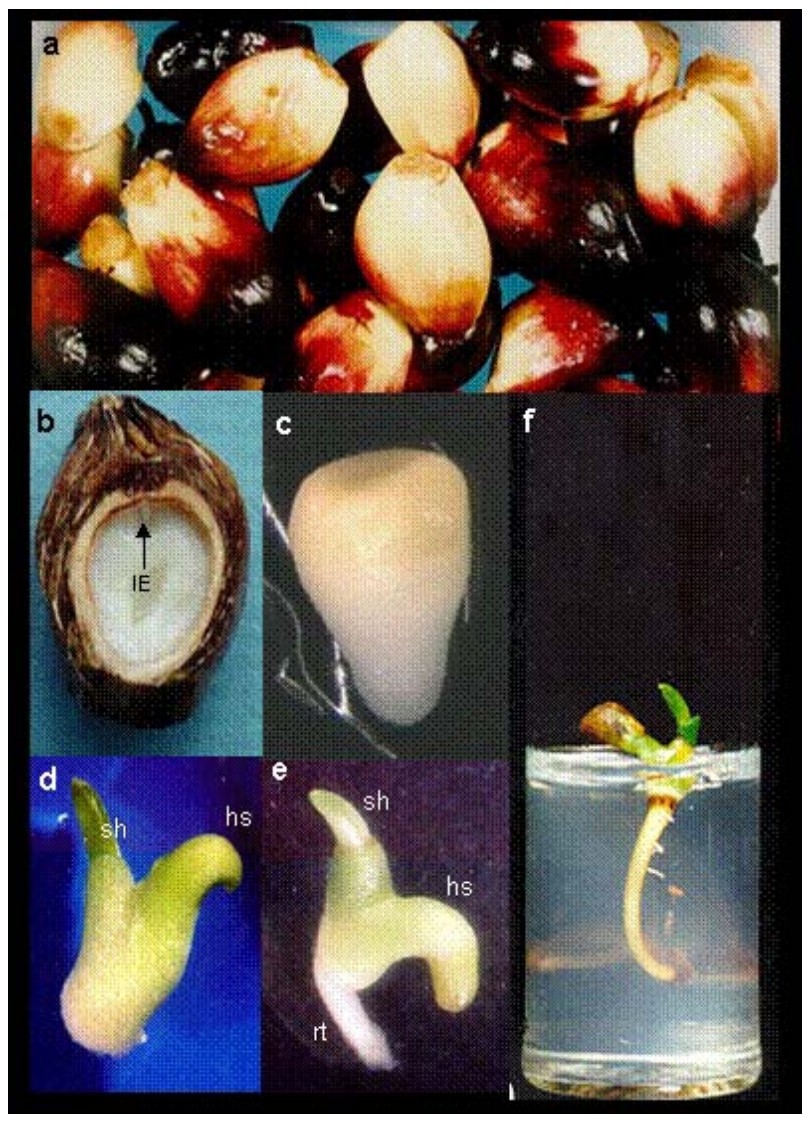

Figure 1. In vitro germination of oil palm immature embryo (IE) for direct plant regeneration.

(a) Detached immature fruits harvested 9 weeks after anthesis (WAA).

(b) Halfed fruit showing location of the IE sorrounded in a semisolid kernel.

(c) Freshly extracted IE on $\mathrm{N}_{6} \mathrm{O}$ media.

(d) Germinating IE after 3 days on $\mathrm{N}_{6} \mathrm{O}$ media, with prominent shoot (sh) and haustarium (hs).

(e) Germinating IE with distinct root (rt), shoot (sh) and haustarium (hs), after 1 week on $\mathrm{N}_{6} \mathrm{O}$ media.

(f) Germinated IE in root development (R68) media.

into protoplasts via electroporation. This, however, is not yet possible for oil palm since the system for complete plant regeneration from protoplasts is not fully established, with only first and second divisions observed (Sambanthamurthi et al. 1996). Nevertheless, the introduction of DNA mediated by particle bombardment would benefit genetic transformation of recalcitrant and perennial crops, like oil palm, the most since, the technique enables the transfer of any gene to virtually any tissues or cell types (Abdullah et al. 1999; Parveez, 2000).

Preliminary studies on the influence of physical parameters and different promoters in assaying genetic transformation events have been reported for oil palm (Parveez et al. 1997; Chowdhury et al. 1997). However, these reports lack substantiated evidence for stable integration of transgenes transferred (Abdullah et al. 2003). Here, we report the potential role of immature embryos (IEs) in genetic transformation studies of oil palm. Results presented include studies on in vitro culture of IE for both direct and indirect plant regeneration, and preliminary studies on the susceptibility of IE to Agrobacterium infection as compared to biolistic-mediated gene transfer system. These would provide new avenues for rapid introduction of new and useful traits into oil palm, which until now, has been dependent solely on conventional means for improvement.

Callus initiation, maintenance and plant regeneration. Alternatively, IEs were cultured on either $\mathrm{N}_{6} 2.5$ or $\mathrm{N}_{6}$ FET and incubated in the dark at $28 \pm 1{ }^{\circ} \mathrm{C}$ for callus induction. Callus were then maintained and sub-cultured every two weeks on the same media. Complete plant regeneration was induced on $\mathrm{N}_{6} \mathrm{O}$ and rooted plants were transferred on R68 for root development.

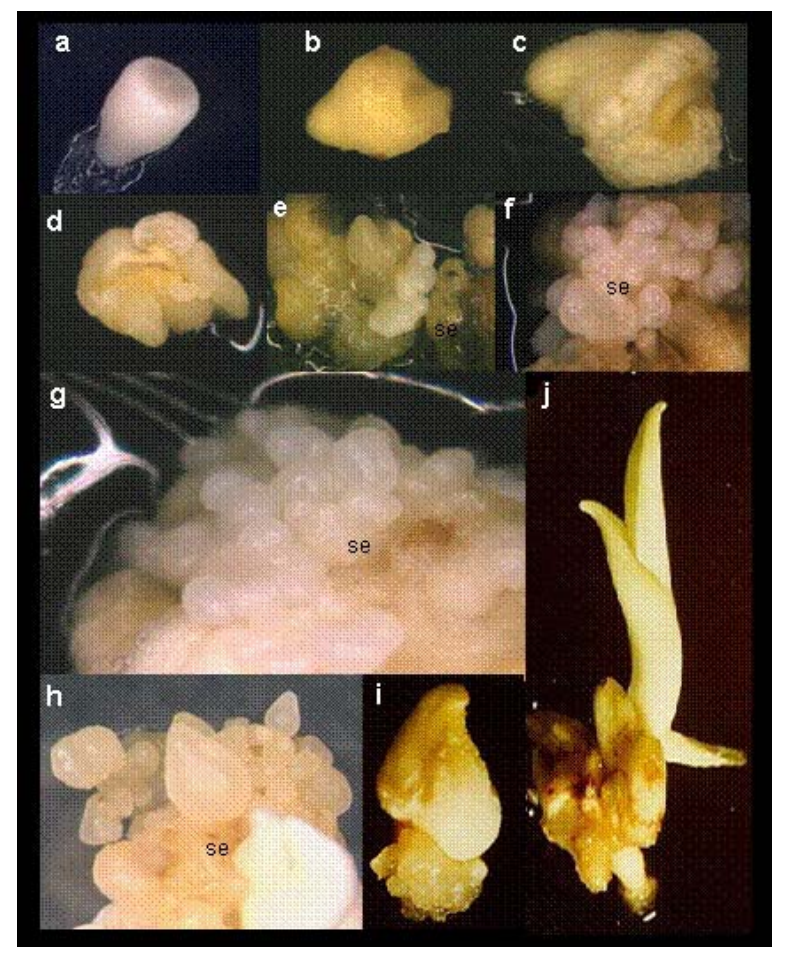

Figure 2. In vitro culture of oil palm immature embryo (IE) leading to plant regeneration via callus stage.

(a) Freshly extracted IE on callusing media $\left(\mathrm{N}_{6} 2.5\right.$ or $\left.\mathrm{N}_{6} \mathrm{FET}\right)$; (b) An IE undergoing expansion after 3 days on callusing media $\left(\mathrm{N}_{6} \mathrm{FET}\right)$.

(c-d) Callusing IE after 4 weeks on callusing media $\left(\mathrm{N}_{6} 2.5\right)$.

(e-g) Somatic embryos developing on embryogenic callus derived from IE after 8 weeks on $\mathrm{N}_{6} \mathrm{FET}$.

(h-i) Distinct torpedo-shaped somatic embryos developing from embryogenic callus following transfer onto $\mathrm{N}_{6} \mathrm{O}$.

(j) Plantlet obtained from germinated somatic embryos on $\mathrm{N}_{6} \mathrm{O}$.

Hardening. Plants with vigourous roots were transferred into polybags and maintained for two weeks in a plastic chamber at $80-95 \%$ relative humidity. Hardened plants were then transferred into bigger polybags and slowly exposed to external conditions over a period of another 2 weeks. 


\section{MATERIALS AND METHODS}

\section{Preparation of plant materials}

In this study, tenera, dura and pisifera varieties of oil palm (Elaeis guineensis Jacq.) were used as sources for IEs. In addition, IEs were also extracted from Elaeis oleifera for comparison. Open-pollinated bunches were harvested 7-13 weeks after anthesis (WAA). Fruitlets were detached from the stalk and washed in soap water. They were immediately soaked in absolute ethanol for $15 \mathrm{~min}$ and air-dried in a laminar flow chamber. Sterilized fruits were halved using scateurs and IEs were extracted from the semi-solid kernel. Extracted IEs were cultured on the respective media (Table 1) and incubated either in light or dark at $28 \pm 11^{\circ} \mathrm{C}$ depending on the objective of the experiment.

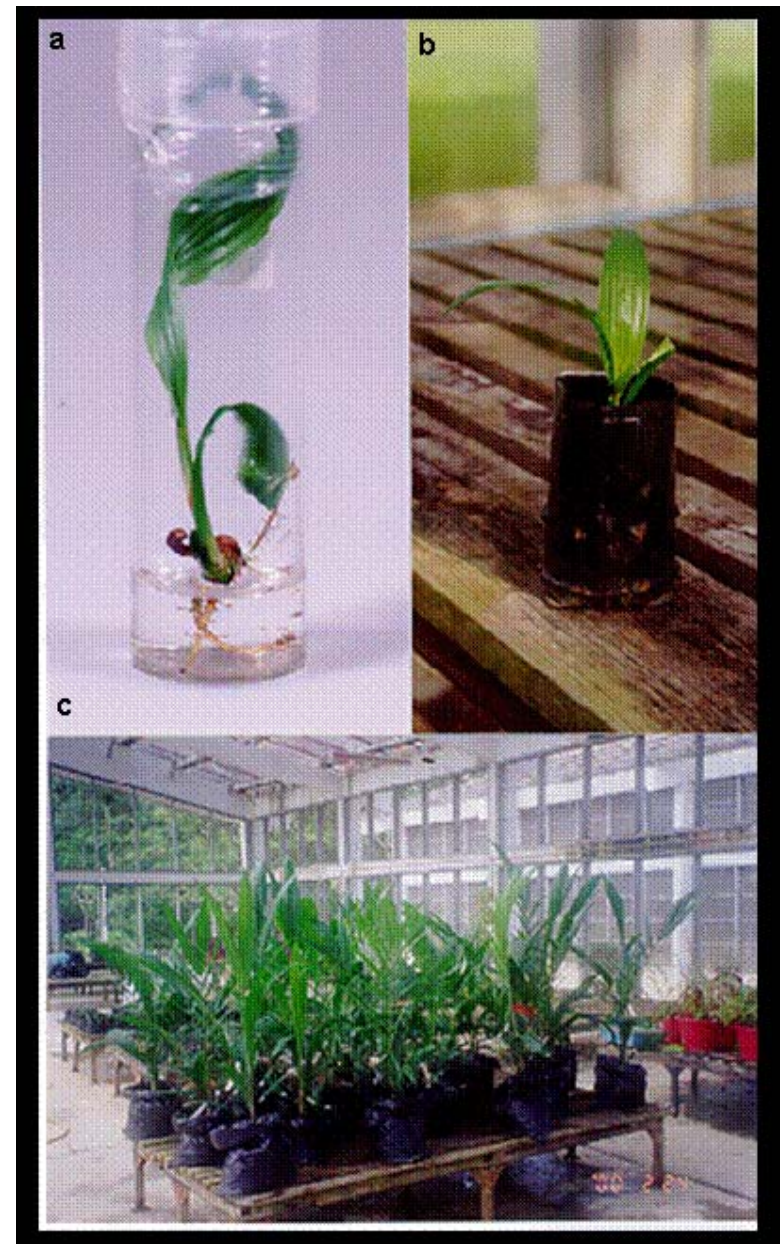

Figure 3. Plants derived from cultured immature embryos.

(a) Plantlet complete with roots ready for hardening

(b) Hardened plant in a polybag.

(c) 1-year old plants in big polybags prior to transfer into soil.

\section{In vitro culture of immature embryos}

Direct plant germination. For direct germination, IEs were cultured on hormone-free $\mathrm{N}_{6}$ media $\left(\mathrm{N}_{6} \mathrm{O}\right.$, Chu et al. 1975) and incubated in the dark at $28 \pm 11^{\circ} \mathrm{C}$ until the first leaf appears. Subsequently germinated IEs were transferred into the light whilst on the same media.

\section{In vitro tolerance of IEs to antibiotics commonly used as selectable markers}

Freshly extracted IEs, IE-derived primary callus (PC), IEderived embryogenic callus (EC) and IE-derived friable embryogenic tissues (FET) were cultured on their maintenance media supplemented with different concentrations of antibiotics commonly used as selectable markers in genetic transformation studies. The antibiotics tested were kanamycin (Km), geneticin (G418), chloramphenicol, hygromycin $(\mathrm{Hm})$ and phosphinotricin. Cultures were sub-cultured every two weeks and observed over a period of 8 passages.

\section{Genetic transformation assessment of IEs using biolistic}

Preparation of DNA-coated gold particles. DNA was isolated according to Abdullah et al. (2003) and was later coated on gold particles described by Sanford et al. (1993). pBI 121 (Clontech) containing neomycin phosphotransferase (NPT II) and b-glucuronidase (GUS) genes were used in all initial transformation experiment.

Bombardment of IEs. Prior to bombardment, freshly prepared DNA-coated gold particles were vortexed for 1 min. For each bombardment $6 \mu \mathrm{l}$ DNA-coated gold particles was placed on the macrocarrier. IEs were bombarded using the Biolistic ${ }^{\mathrm{TM}}$ Particle Delivery System (PDS 1000/He; Bio-Rad). The optimum parameters were determined empirically. They include varying the helium pressure $(900,1100$ and $1300 \mathrm{psi})$, distance between microand macrocarrier $(6,11,16 \mathrm{~mm})$ and size of IEs $(\leq 3,3-6$, and $\geq 6 \mathrm{~mm}$ ) used.

Analyses of putative transformed IEs following bombardment. Bombarded IEs were left undisturbed for two days on the same media $\left(\mathrm{N}_{6} \mathrm{O}\right)$. They were then transferred onto $\mathrm{N}_{6}$ media containing $100 \mu \mathrm{g} / \mathrm{ml} \mathrm{Km}$ $\left(\mathrm{N}_{6} \mathrm{Km} 100\right.$; Table 1) for selection and subsequent regeneration. The presence of GUS activity in bombarded IEs was visualized histochemically using methods described by Parveez and Christou (1998). Assays were carried out at random on IEs, germinating IEs and tissues from plantlets 7 days, 3, 9 and 18 months after bombardment. IEs and plants expressing GUS activity were quantified and were used as the percentage of transient transformation frequency. Callusing assay was carried out on germinating $\mathrm{Km}$-resistant $\left(\mathrm{Km}^{\mathrm{r}}\right)$ IEs 2 months after bombardment. Germinating $\mathrm{Km}^{\mathrm{r}}$ IEs were randomly selected and cross-sectioned. They were then inoculated on $\mathrm{N}_{6} 2.5$ or $\mathrm{N}_{6}$ FET media (Table 1) and maintained in the dark at $28 \pm 1^{\circ} \mathrm{C}$. Calli produced were subsequently assayed for GUS activity. 


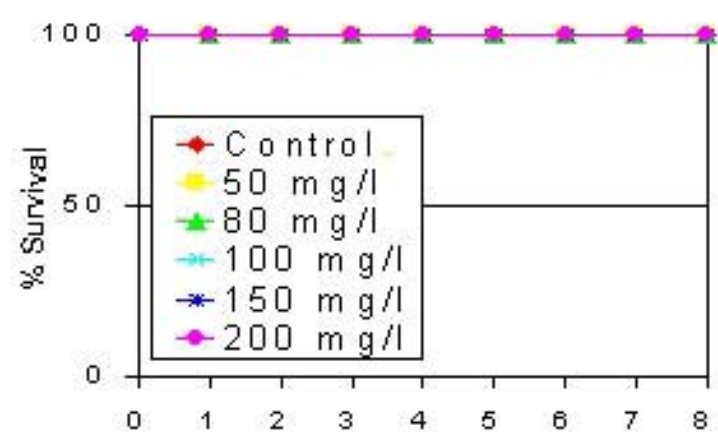

A
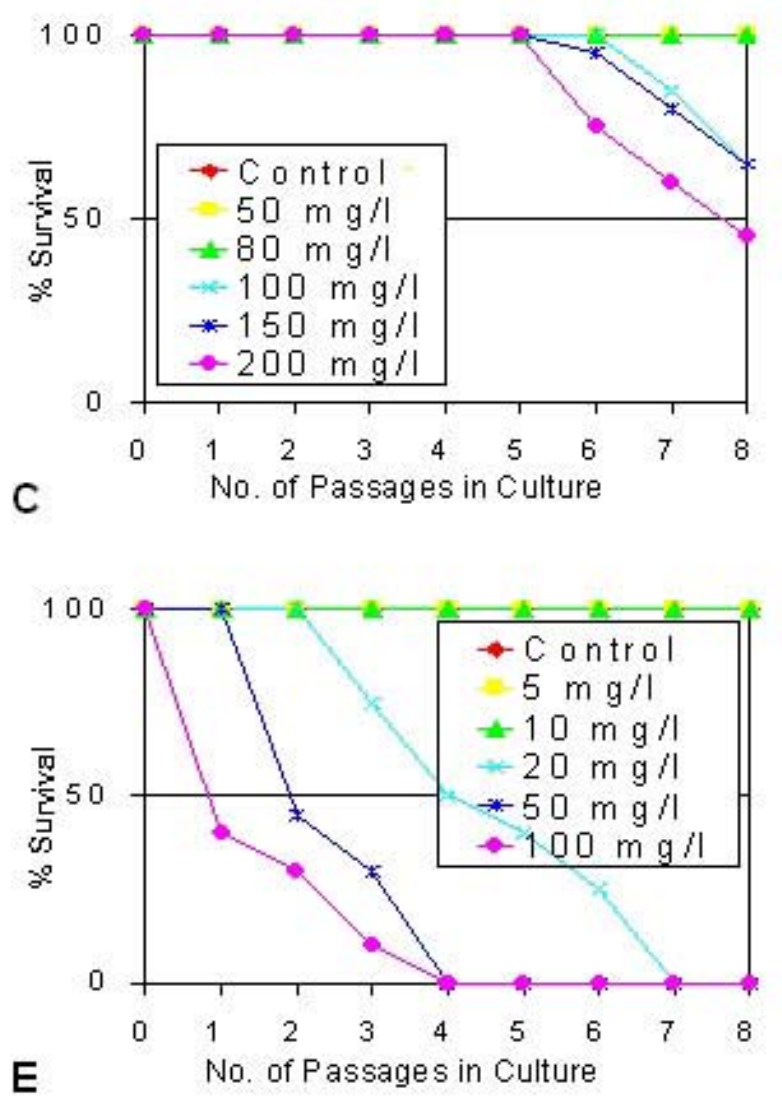
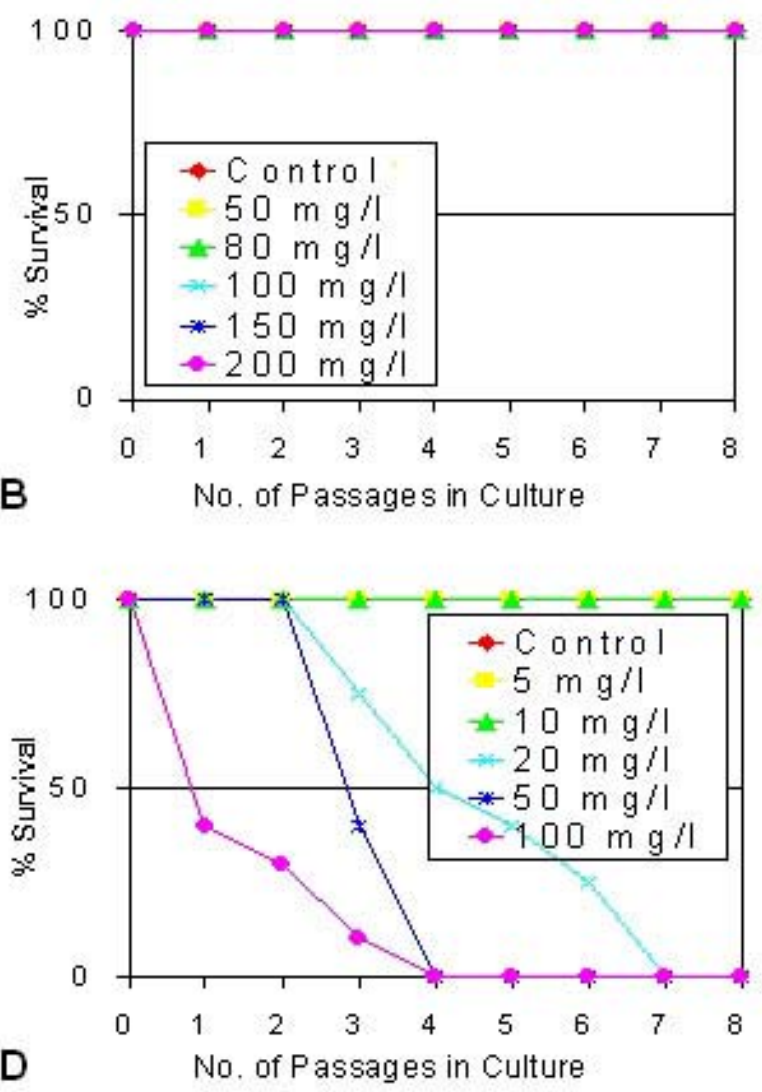

Figure 4. Studies on the in vitro tolerance of oil palm immature embryos (IEs) to various antibiotics commonly used as selectable marker to select putative transformants. Sensitivity of IEs to various concentration of $(A)$ kanamycin (Km); (B) geneticin (G418); (C) chloramphenicol; (D) hygromycin (Hm); and (E) phosphinotricin.

\section{Genetic transformation assessment of IEs using Agrobacterium}

Co-cultivation of IE. 7-day old IEs were co-cultivated for 30 min in $\mathrm{N}_{6} 6$ media (Table 1) containing Agrobacterium tumefaciens LBA4404:pCAMBIA1301. Co-cultivated IEs were then transferred onto either $\mathrm{N}_{6} \mathrm{O}$ or $\mathrm{N}_{6} 2.5$ without blotting and incubated in the dark for 3 days. IEs were again transferred without rinsing onto the same media supplemented with $250 \mathrm{mg} / \mathrm{l}$ cefotaxime $\left(\mathrm{N}_{6} \mathrm{Cf} 250\right.$ or
$\mathrm{N}_{6} 2.5 \mathrm{Cf} 250$ ) and maintained in the light for those cultured on $\mathrm{N}_{6} \mathrm{Cf} 250$, and in the dark for $\mathrm{N}_{6} 2.5 \mathrm{Cf} 250$.

Analyses of putative transformed IEs following cocultivation with Agrobacterium. Histochemical assays were performed according to protocols described by Abdullah et al (2003). Assays were carried out on IEs, germinating IE, callus and tissue from plantlets 7 days, 3, 9 and 18 months after co-cultivation. Putative transformants expressing GUS activity were quantified. 


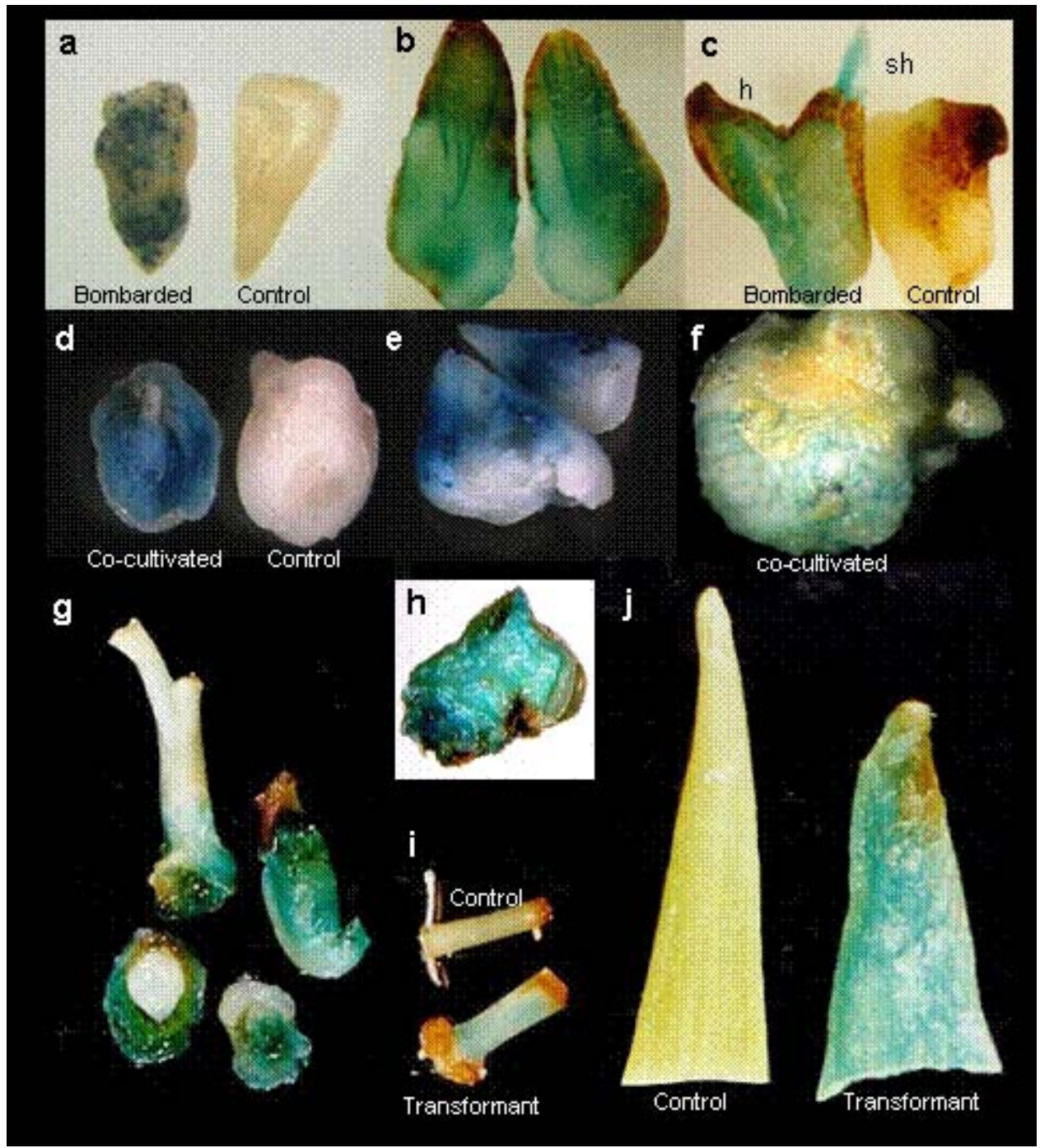

Figure 5. Histochemical GUS assay on bombarded and co-cultivated IEs and their respective IE-derived tissues.

(a) Freshly bombarded les;

(b) Halved-IE 3 days after bombardment showing distinct GUS expression throughout the entire IE with highest expression localised at the meristematic region and areas with actively dividing cells;

(c) Germinating IEs with distinct shoot (sh) and haustarium (h);

(d) Freshly co-cultivated les;

(e) Halved-IE 7 days after co-cultivation showing distinct GUS expression localised at meristematic region and areas with actively dividing cells;

(f) Callusing IE 2 weeks after co-cultivation;

(g-h) Callusing assay, with callus developing on IE-derived tissues expressing gus activity;

(i) Callus developing from roots of plantlets undergoing callusing assay also showing gus activity;

(j) Leaf tissues from IE-derived plantlets showing gus activity. Blue coloration of tissues indicates the expression of GUS gene substantiating successful gene transfer.

\section{Plant regeneration of putative transformed tissues}

Plants regenerated from both bombarded and co-cultivated IEs were further maintained on the same media prior to transfer into soil. GUS assay was again carried out on leaves of developing plants 3,9 and 18 months after transformation either by bombardment or Agrobacterium.

\section{RESULTS AND DISCUSSION}

\section{In vitro culture of immature embryos}

The main prerequisite for an efficient transformation system is the ability to regenerate complete plants from treated target tissues. Unlike other crops, oil palm tissue culture is a very slow process. On average at least 18 months are required to produce complete plants from callus derived from various explants, with callusing rate of about $20 \%$ for young leaf and root explants, as compared to as 
high as $100 \%$ for IEs. On the other hand, IEs isolated from 9-10 WAA fruits, readily germinated into complete plants on hormone-free medium (Figure 1). Germination could reach up to almost $100 \%$. However, culture of IEs isolated from 8 WAA fruits or younger failed to germinate. Furthermore, endosperm from 8 WAA fruits or younger are still soft, thus, resulted in poor recovery of embryos. On an appropriate medium, in this case $\mathrm{N}_{6} 2.5$ and $\mathrm{N}_{6} \mathrm{FET}$, IEs gave rise to callus within 4-6 weeks, much faster than other explants. Though, IEs were equally responsive both media, but those cultured on $\mathrm{N}_{6} \mathrm{FET}$ were less browned compared to those on $\mathrm{N}_{6} 2.5$. Cultured IEs started to swell and expanded after 3 days on callusing media and yielded primary calli within 4-6 weeks (Figure 2). While on the same media, the primary callus produced embryogenic callus with distinct somatic embryos of different shapes and stages. Upon transfer to $\mathrm{N}_{6} \mathrm{O}$, torpedo-shaped embryos germinated into complete plants, completing the whole sequence of in vitro culture of IEs for complete plant regeneration via callus in just about 3-4 months. The reduced time required for IEs to produce callus (in this case 4-6 weeks) as opposed to 8-52 weeks for young leaves, would mean shorter periods in culture. This would reduce the possibility for the onset of chromosomal aberrations that would lead to the production of abnormal plants (Jaligot et al. 2000). Plants with vigorous root systems normally requires between 2-4 weeks to be hardened and were later transferred into polybags prior to transfer into soil (Figure 3).

IEs are abundant, where on average between 300-500 IEs could be extracted from a single developing bunch. The numbers of IEs available enabled large-scale genetic transformation studies to be carried out on oil palm. It was also observed that, both biolistic and Agrobacteriummediated gene transfer into oil palm IEs are not dependent on the variety. All three Elaeis guineensis varieties namely dura, pisifera and tenera and IEs from Elaeis oleifera tested for both biolistic and Agrobacterium-mediated gene transfers were found susceptible to both gene transfer systems. In addition, using IEs as target tissues for genetic transformation studies of oil palm offers an additional advantage where transgenic plants from transformed IEs could be used directly as crossing partners to introduce new or elite genes into specific breeding programs, and with minimum fidelity-associated problems. This would further shorten the breeding cycle for oil palm. However, since IEs are often the product of cross pollination between two separate parents, therefore, they are often non-uniform in terms of their genetic make up, especially if it involved open pollination. A more desirable case would be to transform a self-pollinated dura or pisifera of known parentage. Nevertheless, following theirabundance, highly responsive nature in vitro, reduced clonal fidelityassociated problems, and the ability to allow the introduction of elite genes rapidly, IEs are considered the most suitable target tissues for transformation studies of oil palm.

\section{In vitro tolerance of IE to antibiotics commonly used as selectable markers}

Since the efficiency of plant transformation is less than optimal for many important plant species, thus, the development of transgenic plant requires the use of suitable selectable marker genes. Like most monocots, selectable marker genes that were suitable for dicots may not be suitable for monocots. As such the in vitro tolerance study carried out on various potential target tissues of oil palm serves to facilitate future use of suitable antibiotics for the selection of putative transformants. This would be incorporated in the construction of chimaericgenes constructs for future genetic manipulation studies.

In the in vitro tolerance studies conducted, IEs were insensitive to both $\mathrm{Km}$ and G418 (Figure 4a-b). It was observed that, $\mathrm{N}_{6} \mathrm{O}$ supplemented with as high as $250 \mathrm{mg} / \mathrm{l}$ $\mathrm{Km}$ or G418 did not have any effect on the IEs even after 16 weeks on the media. IEs were slightly sensitive to chloramphenicol where growth was affected when exposed to more than $100 \mathrm{mg} / \mathrm{l}$ (Figure 4c). However, the effect of chloramphenicol on the growth of IE was only observed after 10 weeks in culture. The survival rate after 16 weeks at 100 and $120 \mathrm{mg} / \mathrm{l}$ are $65 \%$, and $45 \%$ at $150 \mathrm{mg} / \mathrm{l}$. Unlike $\mathrm{Km}, \mathrm{G} 418$ and chloramphenicol, both $\mathrm{Hm}$ and phosphinotricin were toxic to oil palm IEs. All IEs exposed to more than $50 \mathrm{mg} / \mathrm{l}$ hygromycin were dead within 8 weeks, and within 14 weeks for exposure at $20 \mathrm{mg} / \mathrm{l}$ (Figure 4d). Similar results were obtained for phosphinotrycin, where all IEs were killed when exposed to $20 \mathrm{mg} / \mathrm{l}$ or more (Figure 4e). The only difference between the effect of Hm and phosphinotrycin on IE was in the rate of IE death recorded. It was more rapid in the case for phosphinotrycin but slightly more gradual for $\mathrm{Hm}$. In all cases, however, control IEs cultured on $\mathrm{N}_{6} \mathrm{O}$ continued to germinate and proliferate into complete plantlets.

Similar results were obtained for other target tissues tested, including primary callus (PC), embryogenic callus (EC) and friable embryogenic tissues (FET), where all PC, EC and FET were insensitive to both $\mathrm{Km}$ and G418, slightly sensitive to chloramphenicol but very sensitive to both $\mathrm{Hm}$ and phosphinotrycin (data not shown).

\section{Genetic transformation assessment of IEs}

Conditions for biolistic-mediated gene transfer for oil palm were optimized using IEs as target tissues, and pBI 121 as the DNA carrying the reporter and marker genes. Determination for optimum conditions was based on histochemical assay carried out randomly on IEs, 3 days after bombardment. It was observed that, all 3 parameters evaluated did not significantly influence transient transformation frequency. Varying the macrocarrier gap from 6 , to 11 or $16 \mathrm{~mm}$, only slightly influence transient transformation frequency but was still not significant (Table 2a). However, even though, increasing macrocarrier 
gap did not increase transient transformation frequency, it was observed that IEs bombarded at a larger macrocarrier gap have a better survival rate. This was shown by higher number of $\mathrm{Km}^{\mathrm{r}}$ plants recovered from IEs bombarded at a gap of $16 \mathrm{~mm}$ as compared to 11 or $6 \mathrm{~mm}$. Higher survival rate could be associated to less detrimental effect caused by the DNA-coated gold particles on cell viability as compared to those bombarded at a gap of 11 or $6 \mathrm{~mm}$. Smaller gap would mean severe damage caused to target cells or tissues and this would mean reduced viability after bombardment. Increasing the helium pressure during bombardment also did not improve transient transformation frequency (Table 2 b). However, as in the case for macrocarrier gap, the survival of bombarded IEs was influenced by the degree of damage caused to the target tissue during bombardment. Here, highest number of $\mathrm{Km}^{\mathrm{r}}$ plants was recovered from IEs bombarded at $900 \mathrm{psi}$, where damage was less severe compared to those bombarded at 1100 or 1300 psi. As in the case for macrocarrier gap and helium pressure, embryo size did not influence transformation frequency. However, larger IEs recorded higher viability after bombardment as shown by the number of $\mathrm{Km}^{\mathrm{r}}$ plants recovered after bombardment (Table 2c). In all cases, gus assay on freshly bombarded IEs exhibited discrete individual blue spots but the spots became less distinct 7 days after bombardment. Instead, gus activity appeared to have spread throughout the entire IEs giving rise to IEs with blue coloration as opposed to light yellow in the case for the controls (Figure 5a-c), indicating successful transgene integration. Further observation on longitudinally sectioned-IE, indicated some degree of localization of gus activity in putative transformants. Gus activity was strongest at meristematic region and in areas known to have actively dividing cells such as shoot and root primordia. This was shown by thick blue coloration of the above regions (Figure 5b), as opposed to light blue or pale yellow in regions known to be made of mature or differentiated tissues.

This report presents for the first time, substantiated evidence on the susceptibility of oil palm tissues to Agrobacterium infection. However, since this study was not designed to elucidate factors affecting Agrobacterium infection on oil palm tissues, thus results presented are preliminary in nature. Nevertheless, it was evident that oil palm tissues upon pretreatments with 2,4-Dcan be made susceptible to Agrobacterium infection. Unlike freshly bombarded IEs, gus assay on freshly co-cultivated IEs exhibited uniform and well spread gus activity as shown in Figure 5d-f. Further evaluation on longitudinally sectionedIE, also indicated some degree of localization of gus activity in putative transformants, suggesting possible influence of the promoter used in both gene delivery systems. These were expected since both the gus gene in pBI121 (biolistic) and pCAMBIA1301 (Agrobacterium) were driven by CaMV35S, a well established constitutive promoter that has been shown most efficient in meristematic region and in areas with actively dividing cells. However, it is noteworthy to note that IEs co- cultivated with pCAMBIA1301 exhibited stronger gus expression as compared to those bombarded with pBI121, suggesting the possible influence of the plasmids used to deliver the transgene into target tissues, and the possible role of pretreatments prior to transformation.

Successful transgene integration was further substantiated from callusing assays on putative transformants. It was observed that callus developing from bombarded and cocultivated IEs subjected to callus initiation on $\mathrm{Km}$ containing (for pBI121) and Hm-containing (for pCAMBIA1301) media, exhibited gus activity as shown in Figure $5 \mathrm{~g}-\mathrm{h}$. Gus assays were also positive on roots and leaves isolated from putative transformants derived from bombarded and co-cultivated IEs (Figure $5 \mathrm{i}-\mathrm{j}$ ). The ability of the above tissues to express gus activities after more than 4 months bombarded or co-cultivated further indicates that the transgene has been successfully and stably integrated into the genome of the putative transformants produced.

\section{CONCLUDING REMARKS}

Our results presented have showed that oil palm tissues especially IEs are amenable to gene transfer. Though this is expected of the versatile biolistic-mediated gene transfer approach, the ability to provide substantiated evidence of successful gene transfer, would add oil palm to the list of monocots, that are not natural hosts of this bacterium, to be successfully transformed by Agrobacterium tumefaciens. The frequency of gene transfer is comparable to other plants systems reported elsewhere. Thus the ability to transfer elite genes leading to the production of transgenic plants would mean oil palm could remain competitive against other oil producing crops such as the annuals, soybean and rapeseed.

\section{REFERENCES}

ABDULLAH, R.; CHARI, C.; WINNIE, Y.S.P. and YEUN, L.H. Transgenic oil palm with stably integrated CpTI gene confers resistance to bagworm larvae. In: VASIL, I.K. ed. Plant Biotechnology 2002 and Beyond: A celebration and a showcase. Kluwer Academic Publishers, 2003, p.163-165.

ABDULLAH, R.; YEUN L.H.; RASHDAN, M.M.; LEAW, C.L.; ALIZAH, Z.; YAP, S.P. and WEE, Y.H. Genetically modified oil palm for pest and disease control. In: Plant Protection in the Tropics: Tropical plant protection in the information age. (15-18th March, 1999, Kuala Lumpur, Malaysia). Malaysian Plant Protection Society. SIVAPRAGASAM, A.; ISMAIL, A.A.; SIDAM, A.K.; CHEAH, U.B.; CHUNG, G.F.; CHIA, T.H.; DZOLKHIFLI, O.; HO, T.H.; HUSSAN, A.K.; LEE, S.S., LIM, J.L.; LUM, K.Y.; MOHAMED, S.; NATHAN, G.; ONG, C.A.; VIJAYSEGARAN, S. and ZAINAL ABIDIN, M.A. eds., 1999, p. 47-50. 
AYRES, N.M. and PARK, D. Genetic transformation of rice. Critical Reviews in Plant Sciences, 1994, vol. 13, no. 3, p. 219-239.

CORLEY, R.H.V. Fifteen years experience with oil palm clones. A review of progress. In: Proceedings of the 1991 PORIM International Palm Oil Congress: Update and Vision. (20-25th September 1993, Kuala Lumpur, Malaysia). Palm Oil Research Institute of Malaysia. JALANI, S.; ARIFFIN, D.; RAJANAIDU, N.; MOHD TAYEB, D.; PARANJOTHY, K.; MOHD BASRI, W.; HENSON, I.E. and CHANG, K.C. eds., 1993, p. 69-79.

CORLEY, R.H.V.; LEE, C.H.; LAW, L.H. and WONG, C.Y. Abnormal flower development in oil palm clones. Planter, 1986, vol. 62, p. 233-240.

CHOWDHURY, M.K.U.; PARVEEZ, G.K.A. and NORIHAN, M.S. Evaluation of five promoters for use in transformation of oil palm (Elaeis guineensis Jacq.). Plant Cell Reports, 1997, vol. 16, no. 5, p. 277-281.

CHU, C.C.; WANG, C.C.; SUN, C.S.; HSU, C.; YIN, K.C.; CHU, C.Y. and BI, F.Y. Establishment of an efficient medium for anther culture of rice through comparative experiments on the nitrogen sources. Science Sinica, 1975, vol. 18. p. 659-668.

GAMBORG, O.L.; MURASHIGE, T.; THORPE, T.A. and VASIL, I.K. Plant tissue culture media. In vitro, 1969, vol. 12, p. 473-478.

GELVIN, S.B. Agrobacterium-mediated plant transformation: The biology behind the "gene-jokeying" tool. Microbiology and Molecular Biology Reviews, 2003, vol. 67 , no. 1 , p. 16-37.

JONES, L.H. An evaluation of the role of cytokinins in the development of abnormal infloresecences in oil palms (Elaeis guineensis Jacq.) regenerated from tissue culture. Journal of Plant Growth Regulation, 1995, vol. 14, no. 3, p.135-142.

JONES, L.H. Propagation of clonal palms by tissue culture. Oil Palm News, 1974, vol. 17, p. 1-8.

JALIGOT, E.; RIVAL, A.; BEULE, T.; DUSSERT, S. and VERDEIL, J.L. Somaclonal variation in oil palm (Elaeis guineensis Jacq.): the DNA methylation hypothesis. Plant Cell Reports, 2000, vol. 7, p. 684-690.

MURPHY, D.J. The future of new and genetically modified oil crops. In: JANICK, J. ed. Perspectives on new crops and new uses. ASHS Press, 1999, p. 216-219.

PARVEEZ, G.K.A. Production of transgenic oil palm (Elaeis guineensis Jacq.) using biolistic techniques. In: JAIN, S.M. and MINOCHA, S.C. eds. Molecular Biology of Woody Plants. Kluwer Academic Publishers, 2000, vol. 2, p. 327-335.
PARVEEZ, G.K.A. and CHRISTOU, P. Biolistic-mediated DNA delivery and isolation of transgenic oil palm (Elaeis guineensis Jacq) embryogenic callus cultures. Journal of Oil Palm Research, 1998, vol. 10, p. 29-38.

PARVEEZ, G.K.A.; CHOWDHURY, M.K.U. and NORIHAN, M.S. Physical parameters affecting transient GUS gene expression in oil palm (Elaeis guineensis Jacq.) using the biolistic device. Industrial Crops and Products, 1997, vol. 6, p. 41-50.

RIVAL, A.; ABERLENC-BERTOSSI, F.; MORCILLO, F.; TREGEAR, J.; VERDEIL, J.L. and DUVAL, Y. Scaling-up in vitro clonal propagation through somatic embryogenesis: the case of oil palms: the example of oil palm (Elaeis guineensis Jacq.). Tissue Culture and Biotechnology, 1999, vol. 3 , no. 2 , p. $74-83$.

RIVAL, A.; BERTRAND, L.; BEULÉ, T.; TROUSLOT, P. and LASHERMES, P. Suitability of RAPD analysis for the detection of somaclonal variants in oil palm (Elaeis guineensis Jacq.). Plant Breeding, 1998, vol. 117, no. 1, p. 73-76.

SAMBANTHAMURTHI, R.; SITI-HASNAH, $P$. and ROSLAN, M.N. Oil palm protoplasts: isolation, culture and microcallus formation. Plant Cell Tissue and Organ Culture, 1996, vol. 46, no. 1, p, 35-42.

SANFORD, J.C.; SMITH, F.D. and RUSSEL, J.A. Optimizing the biolistic process for different biological applications. Methods in Enzymology, 1993, vol. 217, p. 483-509.

TEXEIRA, J.B.; SONDAHL, M.R. and KIRBY, E.G. Somatic embryogenesis from immature infloresecences of oil palm. Plant Cell Reports, 1994, vol. 13, no. 5, p. 247250 .

TEXEIRA, J.B.; SONDAHL, M.R. and KIRBY, E.G. Somatic embryogenesis from immature zygotic embryos of oil palm. Plant Cell, Tissue and Organ Culture, 1993, vol. 40, p. 105-111. 